\title{
The Effect of Job Satisfaction on Employee Turnover Intention: Case Study in Tanadewa Resort and Spa Ubud
}

\author{
I Putu Very Ferrari1', I Gusti Gede Anggareksa Putra Mulyawan², I Gusti Agung Gede \\ Witarsana*3, Putu Gde Arie Yudhistira $^{4}$ \\ 1,2,3Program Studi Administrasi Perhotelan, Politeknik Pariwisata Bali \\ Jl. Dharmawangsa, Benoa, Kec. Kuta Sel., Badung, Bali, Indonesia \\ ${ }^{4}$ Program Studi Manajemen Bisnis Perjalanan, Politeknik Pariwisata Bali \\ Jl. Dharmawangsa, Benoa, Kec. Kuta Sel., Badung, Bali, Indonesia \\ 1veryferrari99@gmail.com, 2anggaputram1997@gmail.com, *3agung.witarsana@gmail.com \\ ${ }^{*}$ Corresponding author
}

\begin{tabular}{l|l|l} 
Received: October, 2021 & Accepted: November, 2021 & Published: December, 2021 \\
\hline
\end{tabular}

\begin{abstract}
Employee turnover can cause problems within hospitality business. Job satisfaction commonly influence employee turnover intention. Tanadewa Resort and Spa, Ubud has high annual turnover rate. This research's objective is to analyze the impact of job satisfaction on employee turnover in Tanadewa, Ubud. This research has total population of 48 respondents. Open question is also used to collect qualitative data within the questionnaire. The research uses Simple Linear Regression as analysis method. The result shows job satisfaction has a negative effect to employee turnover intention for $83,7 \%$. The research recommends Tanadewa, Ubud to consider increasing the salary in term of service payment and increase the promotion opportunities.
\end{abstract}

Keywords: job satisfaction, turnover intention, human resources

\begin{abstract}
Abstrak
Turnover karyawan dapat menyebabkan masalah dalam bisnis perhotelan. Kepuasan kerja mempengaruhi intensi turnover. Tanadewa Resort and Spa, Ubud memiliki tingkat turnover tahunan tinggi. Penelitian ini bertujuan untuk menganalisis pengaruh kepuasan kerja terhadap turnover karyawan di Tanadewa, Ubud. Penelitian ini memiliki total populasi 48 responden. Pertanyaan terbuka juga digunakan dalam pengumpulan data kualitatif. Penelitian ini menggunakan Regresi Linier Sederhana. Hasil penelitian menunjukkan kepuasan kerja berpengaruh negatif terhadap turnover intention karyawan dengan kekuatan pengaruh sebesar 83,7\%. Penelitian ini merekomendasikan Tanadewa, Ubud mempertimbangkan peningkatan gaji dalam hal pembayaran layanan dan meningkatkan peluang promosi.
\end{abstract}

Kata kunci: kepuasan kerja, keinginan pindah, sumberdaya manusia 
The Effect Of Job Satisfaction On Employee Turnover Intention In Tanadewa Resort And Spa Ubud

I Putu Very Ferrari, I Gusti Gede Anggareksa Putra Mulyawan, I Gusti Agung Gede Witarsana, Putu Gde Arie Yudhistira

\section{INTRODUCTION}

The human factor or employee is an important resource of hotel organization. Excellent service companies know that positive employee attitudes will promote stronger customer loyalty that led to more profitability (Kotler, 2012). Hospitality industry is known as a labor-intensive industry. Thus, from the human resource perspective, it is creating the challenge to develop proper talent management in managing human resources.

Employee turnover is a phenomenon that often occurs in the hospitality industry. Employee turnover refers to the number of employees leaving the organization, while the desire of employees to move (turnover intentions) refers to the results of individual evaluations regarding the continuation of relationships with the organization that have not been realized in the definite actions of leaving the organization (Witasari, 2009).

High employee turnover can cause a serious problem especially hospitality industry. Woods and Macaulay (1989) explain that high turnover in the hospitality industry can disrupt operations, lower the organization performance, and also inflate costs related to human resources. Thus, addressing the factors that cause turnover is vital to retain potential and talented employees as well as to reduce excess expenditure associated with turnover.

Tanadewa Resort \& Spa, Ubud is one of the hotels in Ubud, Bali that keep facing the challenges of employee turnover. Tanadewa Resort \& Spa is a 5-star Resort that located in Jl. Padang Getas, Singakerta, Ubud, Gianyar Regency with a total employee of 48 people as the research was conducted. The annual turnover rate from Tanadewa Resort and Spa since its opening in March 2019 to April 2020 has accounted for 24,13\% with upward trend during the year. According to Roseman (1981) as cited in Meirina, et al. (2018), an annual turnover can be categorized high when the turnover rate is more than $10 \%$.

An interview with Human Resources Manager of Tanadewa Resort \& Spa Ni Luh Putu Utami revealed the frequent turnover in Tanadewa had caused a lower operational performance due to new recruits often quit before able to grasp the service standard of the hotel. This ineffectively occurs due to the loss of experienced employees, as the management fail to retain them. This disruption not only affecting the recuring costs of recruitment and training but also the result of end service given by newer employees.

Previous studies revealed turnover intention is heavily influenced by job satisfaction. Job satisfaction has a significant negative effect on turnover intentions (Lee and Mowday, 1987; DeMico and Reid, 1988; Poznanski and Baline, 1997; Anis, et al., 2003). Researchers note that employees who expressed high overall job satisfaction were less likely to leave their jobs than workers who expressed lower job satisfaction.

According to Vroom (1964) as cited in Poznanski \& Baline (1997), he described job satisfaction as "having a positive attitude towards individual work." Research evidence on job satisfaction can be divided into several categories, such as leadership, psychological needs, appreciation for effort or effort-reward, management of ideology and values, job design factors and content of work. There is an implication of job dissatisfaction in Tanadewa Resort \& Spa, Ubud that can be identified through the relationship between coworkers. Co-workers is one of the dimensions of job satisfaction that influence turnover intention (Luthans, 2006).

It is vital for Tanadewa Resort \& Spa, Ubud to urgently address turnover intention behavior with job satisfaction as its predictor. The gap between the ideal turnover rates with the phenomenon occurs in Tanadewa Resort \& Spa, Ubud. It is done in order to retain experienced and talented employees as well as to reduce cost associated with turnover. 


\section{RESEARCH METHOD}

This research used descriptive statistical method to present quantitative description in a manageable form. This research also uses qualitative data to enhance the quantitative data. This method allows researcher to explore diverse perspectives between the relationships of job satisfaction and turnover intention. Thus, a descriptive statistical approach along quantitate research component can give better understanding of the problem and enrich the evidence discovered.

Furthermore, primary and secondary data were collected in this research. The primary data was obtained with questionnaire, interview and observation. The secondary data was obtained from the hotel in the form of the employee turnover data summary. Other supporting data include books and journal articles.

This research uses total population sampling where the entire population of 48 employees in Tanadewa Resort \& Spa, Ubud from Administration \& General, Housekeeping, Food \& Beverage (Service \& Production), Engineering, and Spa are involved to analyze the effect of job satisfaction on employee turnover intention variables.

Job satisfaction is measured with 15-questions of Luthans (2006) 5 job satisfaction dimensions; work itself, salary, promotion opportunities, supervision, and coworker. Turnover intention is measured with 3-questions of voluntary turnover process derived from Lum et al., (1998). Both variables are combined in a five-point Likert's scale. (1= strongly disagree/dissatisfied; 2 = disagree/dissatisfied; $3=$ neutral; $4=$ agree/satisfied; 5 = strongly agree $/$ satisfied).

The validity and reliability were tested. The validity was tested with Pearson Product Moment in SPSS where $r$ counts higher than $r$ table. The results have shown that $r$ count is higher than 0.284 , meaning all items are valid. The reliability was tested with Cronbach Alpha value more than 0.6 (Ghozali, 2013). Reliability test results indicate that Cronbach Alpha score for job satisfaction is 0.818 and turnover intention of 0.778 , meaning the items are reliable to be used.

Data analysis technique used includes descriptive analysis using mean score, cross tabulation, classic assumption test (normality, linearity, heteroscedasticity, and autocorrelation), and simple linear regression analysis, including open question analysis.

\section{RESULT AND DISCUSSION}

\subsection{Data Description}

The data were collected from Google Form acquired consisting of the information of the characteristics of the respondents from their age, gender and academic background.

Table 1: Characteristics of Respondents

[Source: Researcher Analytic Data]

\begin{tabular}{lll}
\hline Characteristics & Frequency (n=48) & Percentage (\%) \\
\hline Age Range & 9 & \\
$20-25$ & 24 & $19 \%$ \\
$26-30$ & 12 & $50 \%$ \\
$31-35$ & 3 & $25 \%$ \\
$>35$ & & $6 \%$ \\
Gender & 34 & - \\
Male & 14 & $71 \%$ \\
Female & & $29 \%$ \\
Academic Background & 36 & $75 \%$ \\
Senior High School (SMA/SMK) & 8 & $17 \%$ \\
Diploma (D1/D2/D3) & 48 & $100 \%$ \\
Diploma 4 / S1 & &
\end{tabular}


Table 1 shows the information of respondents' characteristics that were examined for the sample $(\mathrm{N}=48)$. The respondents were dominantly in the age range of 26-30 years for (50\%), followed by 31-35 years age range for (25\%), 20-25 years for (19\%) and the smallest age group with the range older than 35 years old for only (6\%). The respondents were male dominant for (71\%) and with female only for (29\%). Only (8\%) of the respondents were coming from Senior High School (SMA/SMK) and (17\%) were Diploma 4 / S1 graduate. Most of the respondents have Diploma (D1/D2/D3) for (75\%).

Descriptive statistic is used to determine the result of questionnaire on each variable which Job Satisfaction and Turnover Intention. Mean score is used to find categorization of conditions of job satisfaction and turnover intention of employees at Tanadewa Resort and Spa Ubud.

Table 2: Characteristics of Respondents

[Source: Sini, et al., 2015]

\begin{tabular}{ccc}
\hline NO & Mean Score & Level of Satisfaction \\
\hline 1 & $1.00-1.80$ & Strongly Disagree \\
2 & $1.81-2.60$ & Disagree \\
3 & $2.61-3.40$ & Neutral \\
4 & $3.41-4.20$ & Agree \\
5 & $4.21-5.00$ & Strongly Agree \\
\hline
\end{tabular}

Based on the criteria of mean score in Table 2, the results of the analysis using the mean score that measures job satisfaction and turnover intention are summarized for each dimension.

Table 3: Mean Score of Job Satisfaction

[Source: Researcher Analytic Data]

\begin{tabular}{llll}
\hline No & Dimension & Mean Score & Meaning \\
\hline Job Satisfaction & - & \\
1 & Work Itself & 4,22 & Strongly Agree \\
2 & Salary & 4,03 & Agree \\
3 & Promotion Opportunities & 4,08 & Agree \\
4 & Supervision & 4,42 & Strongly Agree \\
5 & Coworkers & 4,76 & Strongly Agree \\
Turnover Intention & - & \\
1 & Turnover Intention & 1.81 & Disagree \\
\hline
\end{tabular}

Table 3 shows the highest mean of job satisfaction is in the coworkers dimension. Meanwhile, the lowest mean is found in the salary dimension followed by promotion opportunities dimension, which implies the lowest job satisfaction, among other dimensions. Judging from the variables, job satisfaction of employees at Tanadewa Resort and Spa Ubud is categorised as strongly satisfied. However, the two lowest dimensions of salary and promotional opportunities need to be improved for better. The score indicates some respondents are barely satisfied with the salary that received for their responsibility in workplace. To understand deeper, the two dimensions of the job satisfaction variable will be cross tabulated two factor: age and work department.

From the result of tabulated data and interview collected for salary dimension, there is an indication that some of the younger employee within the age range of 21-30 tend to slightly dissatisfy with the salary they received for their work responsibility compared to the employees aged group $>30$. These employees tend to work harder compared to the older employee aged $>30$ with the same salary. This is in line with the statement of Nitisemito (2000), that stated young employees within age range of 21-30 tend to be 
physically strong, so they will work harder with same compensation as the older counterpart in the same job position.

Some of the employees within age range of 21-30 think that the salary and benefits given for their work is not always better than the competitors. These employees have higher salary expectation. Meanwhile some employees on the age range of $>30$ somewhat satisfied. It is supported by Robbins (2003) in Yasin \& Priyono (2016) in which the older the employee has higher commitment to the organization due to the opportunity for individuals to get other jobs becomes limited as the got older while younger generation have tendency of salary and benefits comparison.

Only a small fraction of employees within the age range of 21-30 feels that they were not rewarded well for their hard work. However, the majority of employees with age range of $>30$ feels they received decent reward for their loyalty on the organization. Shafira (2017) explains that employees who serve organization for long would receive retirement benefits and monetary reward for long service.

From the perspective of the department where the employee works, most of the slight dissatisfaction related to salary, benefits, and reward are from the Housekeeping and F\&B Service \& Production Department. It happens due to service charge is not equal with their effort for a long working hours, irregular schedule and operational activities that consume significant energy.

Furthermore, the analysis of tabulated data and interview for promotional opportunities indicates that two employees within age range of 26-35 are slightly dissatisfied with the basis and benchmark used for promotion. Then, only one employee with similar age range feels dissatisfied with opportunity to get a promotion. In addition, five employees ranging from the age 21-30 were dissatisfied with the job promotion frequency that occurs in the company. These dissatisfied employees hope that the job promotion can occur for at least twice opportunity a year.

In term of turnover intention which refers to the table 3 above, it shows that most of the employees don't exhibit intention to leave the company. However, the cross-tabulation of two factors; age and work department indicate that some employees exhibit intention to leave the company which need to be addressed by Tanadewa Resort.

In this regard, respondents of age range 26-30 have more turnover intention compared to those new employee age range 21-25 and above 31 years old. It is evident that some respondent from these age group (26-30) more than other respondents in different age range consistently has shown tendency to have thought of quitting the job, consider another job and leaving current company. Based on the interview, the respondents from these age range wants to seek more experience and in search of opportunity for career growth. On the other hand, younger employees age range 21-25 as new hires tend to stay in the company to explore and learn the work environment and culture. Meanwhile older employees above 31 years old tend to stay longer and exhibit less turnover intention to better support their family and to acquire benefits and compensation for long service given to the company.

Related toward work department, it is noted that some respondents from housekeeping department exhibit the most of turnover intention than any other department in Tanadewa Resort. Furthermore, most other departments such as Administration \& General, Food \& Beverage, Spa, and Engineer are disagreed and keep neutral, exhibiting least turnover intention.

Open question is used to enrich the qualitative data and provide an insightful analysis toward the findings. The objective of this open question was to analyze the most important factors of five job satisfaction factors (Job, Salary, Promotion, Supervisor and Coworkers) in Tanadewa Resort. 


\begin{tabular}{ccc}
\hline NO & Factor & Percentage $\%$ \\
\hline 1 & Work & $4,17 \%$ \\
2 & Salary & $37,50 \%$ \\
3 & Promotion & $34,72 \%$ \\
4 & Supervisor & $1,39 \%$ \\
5 & Co-workers & $22,2 \%$ \\
\hline
\end{tabular}

Based on the table 4, it is identified that the most important factor in job satisfaction is salary followed by promotion while the least important according to the respondents of Tanadewa Resort is supervisor. In this regard, the employees prefer to have more promotion for career advancement and consider a good pay from the company. While not prevalent, factors like co-workers are still pSreferred by moderate group of employees. This group value the importance of co-workers in their workplace rather than salary and promotion.

\subsection{Data Analysis}

Classic assumption test is prerequisite to qualify the quality of data before conducting linear regression analysis (Ghozali, 2018). Therefore, the test of normality, linearity, heteroscedasticity, and autocorrelation were used in this research by displaying the following results.

Normal probability plot is used to compare actual cumulative distribution of data with the cumulative distribution of the normal distribution (hypothetical distribution). The results show the normal P-P plot of regression standardized residuals always follow and approach the diagonal line as can be seen on the figure 1 below. Meaning the residuals of the data in this research are normally distributed.

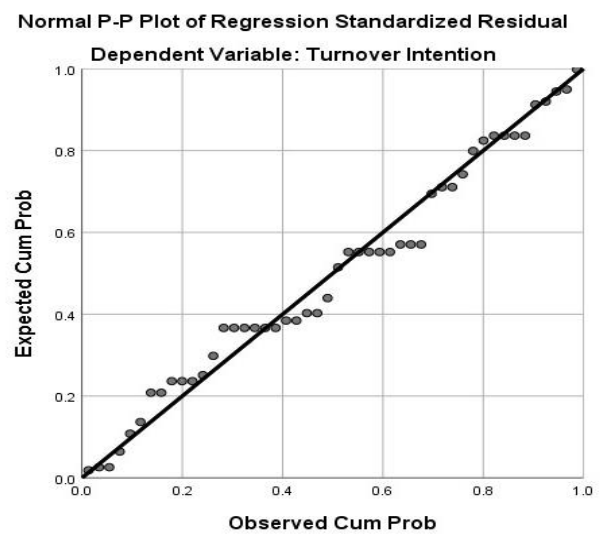

Figure 1. Normality Test

[Source: Researcher Analytic Data]

Linearity test aim to determine the linearity relationship between independent variables and dependent variable. The results of the linearity test using scatterplot in SPSS as can be seen in figure 2 below shows the regression model in this study has linearity with negative correlation between the variable. 


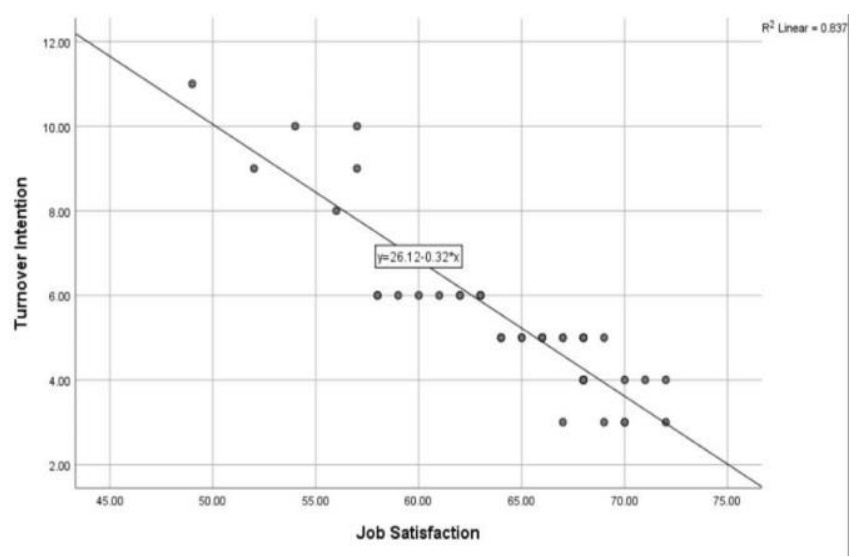

Figure 2. Linearity Test

[Source: Researcher Analytic Data]

This test aims to determine whether there is a similarity in the value of residuals for all regression observation models. Using scatterplot, the output shown in figure 3 below indicate the regression model is good and ideal to use to perform a simple linear regression test. The scattered dots are placed above and below or around the number 0 . The spread of the dots does not form a wavy pattern and the spread of the dots is not patterned. Thus, it no heteroscedasticity problem in this model.

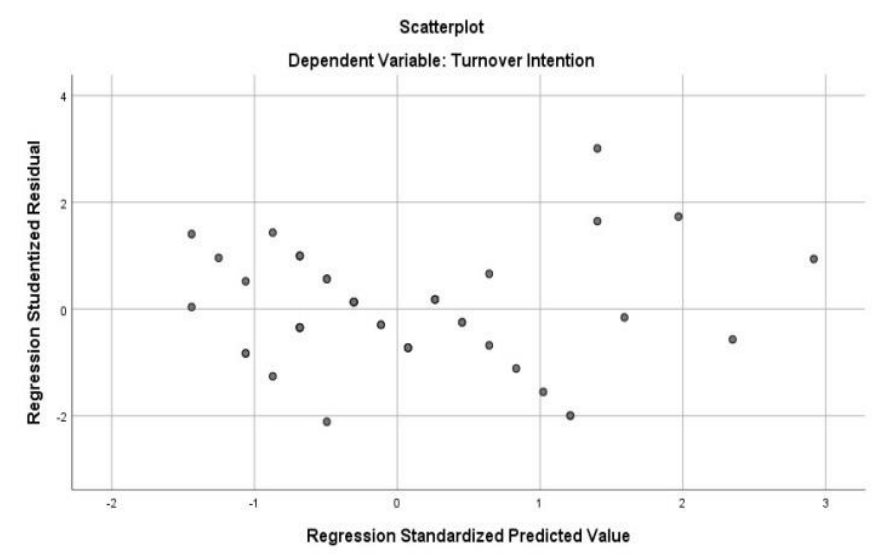

Figure 3. Heteroscedasticy Test

[Source: Researcher Analytic Data]

In a good regression model, autocorrelation should not occur. This study uses Durbin Watson method to test the autocorrelation. The value of Durbin Watson based on table 5 below was 2.25 located between $\mathrm{dL} 1.49$ and dU1.57 with $4-\mathrm{dU}$ is 2.43 . Thus, no autocorrelation identified.

Table 5: Heteroscedasticy Test

[Source: Researcher Analytic Data]

\begin{tabular}{|c|c|c|c|c|c|}
\hline \multirow[b]{2}{*}{ Model } & \multicolumn{4}{|c|}{ Model Summary ${ }^{b}$} & \multirow[b]{2}{*}{ Durbin-Watson } \\
\hline & $\mathrm{R}$ & R Square & $\begin{array}{l}\text { Adjusted R } \\
\text { Square }\end{array}$ & $\begin{array}{c}\text { Std. Error of the } \\
\text { Estimate }\end{array}$ & \\
\hline 1 & $.915^{\circ}$ & .837 & .833 & .75711 & 2.250 \\
\hline
\end{tabular}


Simple linear regression analysis was performed to examine how well job satisfaction predicts employee turnover intention.

Table 5: Result of Simple Linear Regression Test [Source: Researcher Analytic Data]

\begin{tabular}{|c|c|c|c|c|c|c|}
\hline \multicolumn{7}{|c|}{ ANOVA $^{a}$} \\
\hline & & Sum of Squares & df & Mean Square & $\mathrm{F}$ & Sig. \\
\hline \multirow[t]{3}{*}{1} & Regression & 135.299 & $\overline{1}$ & 135.299 & 236.034 & $.000^{\mathrm{b}}$ \\
\hline & Residual & 26.368 & 46 & .573 & & \\
\hline & Total & 161.667 & 47 & & & \\
\hline
\end{tabular}

The output of the test based on table 5 above shown that the $\mathrm{F}$ Count value is 236.034 with a significance level of $0.00<0.05$, therefore the regression model can be used to predict the turnover intention variable, or the job satisfaction variable influences the turnover intention variable.

The $\mathrm{R}$ square value in coefficient of determination test determine how strong is the effect of variable $\mathrm{X}$ on variable $\mathrm{Y}$.

Table 6: Model Summary of Simple Linear Regression Test

[Source: Researcher Analytic Data]

\begin{tabular}{|c|c|c|c|c|}
\hline Model & $\mathrm{R}$ & R Square & $\begin{array}{c}\text { Adjusted R } \\
\text { Square } \\
\end{array}$ & $\begin{array}{c}\text { Std. Error of the } \\
\text { Estimate }\end{array}$ \\
\hline 1 & $.915^{a}$ & .837 & .833 & .75711 \\
\hline
\end{tabular}

The R square $\left(R^{2}\right)$ between job satisfaction and turnover intention is 0.837 , meaning the ability of job satisfaction explaining the variance of turnover intention $(\mathrm{Y})$ is $83,7 \% \%$. Thus, there is a negative significant impact of job satisfaction on employee turnover intention in Tanadewa Resort \& Spa, Ubud.

The t-test was used to determine whether the independent variable and dependent variable can be significantly or partially impacted. If the t-value is higher than the t-table, then the hypothesis 1 (H1).

Table 5: Model Summary of Simple Linear Regression Test

[Source: Researcher Analytic Data]

\begin{tabular}{|c|c|c|c|c|c|c|}
\hline \multirow[b]{3}{*}{ Model } & & \multicolumn{2}{|c|}{ Coefficients $^{a}$} & \multirow{3}{*}{$\begin{array}{c}\text { Standardized } \\
\text { Coefficients } \\
\text { Beta } \\
\end{array}$} & \multirow[b]{3}{*}{$t$} & \multirow[b]{3}{*}{ Sig. } \\
\hline & & \multicolumn{2}{|c|}{ Unstandardized Coefficients } & & & \\
\hline & & $\mathrm{B}$ & Std. Error & & & \\
\hline 1 & (Constant) & 26.116 & 1.352 & & 19.320 & .000 \\
\hline & Job Satisfaction & -.321 & .021 & -.915 & -15.363 & .000 \\
\hline
\end{tabular}

a. Dependent Variable: Turnover Intention 
The value of the regression coefficient of job satisfaction based on table 5 is the 15,363 ( $t$-value) is higher than 2,011 ( $\mathrm{t}$-table). Meaning that job satisfaction has a negative effect on turnover intention. Furthermore, the significance level is identified 0.000, meaning the model is smaller than 0,05 which indicate a significant impact on the turnover intention.

it can be concluded that the null hypothesis ( $\mathrm{H} 0$ ) is rejected, and alternative hypothesis $(\mathrm{Ha})$ is accepted. Therefore, the job satisfaction has negative and significant effect on turnover intentions of Tanadewa Resort \& Spa, Ubud.

\section{CONCLUSION}

Based on the discussion, the job satisfaction has a significant negative impact to the employees of Tanadewa Resort Ubud. A high job satisfaction will reduce employee turnover intention. Overall, the employees of Tanadewa Resort Ubud are considered satisfied and do not exhibit any significant (low) turnover intention. The highest satisfaction present in co-workers' dimension, while the lowest is salary. Salary and promotion dimension are identified to play a major role in retaining and rewarding high quality employees. The hotel might still be vulnerable to turnover intention due to some employees still not satisfied and may poses to turnover intention but in the end, the employees still choose not to leave Tanadewa Resort Ubud. However, there are 3 employees aged 21-30 that dissatisfied with their salary and promotion considering leaving the company immediately.

To maintain high job satisfaction, the hotel is suggested to adjust the wages and salary policies to the current trend in the job market and improve the budget of service payment of operational employee. Furthermore, in order to retain physically strong and more productive younger employees it is also vital for Tanadewa Resort Ubud to create career advancement plan and internal promotion for a better promotion opportunity.

\section{ACKNOWLEDGEMENT}

The authors would like to thank the management of Tanadewa Resort Ubud for their support and help so that this study could be completed and in the present form.

\section{REFERENCES}

Ainiyah, N., Deliar, A. \& Virtriana, R. (2016). The Classical Assumption Test to Driving Factors of Land Cover Change in the Development Region of Northern Part of West Java. The International Archives of the Photogrammetry.

Ali, N., 2008. Factors Affecting Overall Job Satisfaction and Turnover Intention. Journal of Managerial Sciences, Vol.2(No.2).

Anis, I., Ardiansah, M. N. \& Sutapa. (2003). Pengaruh Kepuasan Kerja dan Komitmen Organisasional Terhadap Keinginan Berpindah Kerja Auditor. Jurnal Ekonomi dan Bisnis, Vol. 4(No. 2), pp. pp. 141-152.

Arikunto, S. (2012). Prosedur Penelitian Suatu Pendekatan Praktek. Jakarta: Rineka Cipta.

Biswakarma, G. (2016). Organizational Career Growth and Employees" Turnover Intentions: An empirical evidence from Nepalese Private Commercial Banks. Journal of Organization Behavior and Human Resource Management, Vol. 3(No. 2), pp. pp. 10-26..

Bowen, G. A. (2009). Document Analysis as a Qualitative Research Method. Qualitative Research Journal. Volume Vol. 9, pp. pp. 27-40.

Cooper, D. R. \& Schindler, P. S. (2014). Business Research Methods. Twelfth Edition ed. New York: McGraw-Hill/Irwin.

DeMico, F. J. \& Reid, R. D. (1988). Older Workers: A Hiring Resource for Hospitality Industry. Cornell Hotel and Restaurant Administration, pp. pp. 56-62. 
Etikan, I., Musa, S. A. \& Alkassim, R. S. (2016). Comparison of Convenience Sampling and Purposive Sampling. American Journal of Theoretical and Applied Statistics, Vol.5(No.1), pp.pp.1-4.

Ghozali, I. (2013). Aplikasi Analisis Multivariate dengan Program IBM SPSS 21 Update PLS Regresi. Semarang: Badan Penerbit Universitas Diponegoro..

Hayes, D. K. \& Ninemeier, J. D. (2009). Human Resources Management in. New Jersey: John Wiley \& Sons.Inc.

Hermawan, H., Brahmanto, E. \& Hamzah, F. (2018). Pengantar Manajemen. Pekalongan: PT. Nasya Expanding Manajemen. 72

Hom, P. W., Lee, T. W., Shaw, J. D. \& Hausknecht, J. P. (2017). One Hundred Years of Employee Turnover Theory and Research. Journal of Applied Psychology, Vol. 102(No. 3), p. pp. $530-545$.

Kabir, S. M. S. (2016). Methods of Data Collection. Basic Guidelines for Research. pp. pp. 201- 276.

Khalaf, S. N., Morsy, M. A., Ahmed, G. S. \& Ali, N. A. (2016). Impact of Effective Training on Employee Performance in Hotel Establishments. Journal of Faculty of Tourism and Hotels, Fayoum University, Vol. (10)(No (1/2)).

Khan, A. H. \& Aleem, M. (2014). Impact of Job Satisfaction on Employee Turnover: An Empirical Study of Autonomouse Medical Institution of Pakistan. Journal of International Studies, Vol.7(No.1), pp. pp. 122-132.

Kotler, P. (2012). Marketing Management 14th Edition. 14 ed. Prentice Hall, One Lake Street,Upper Saddle River, New Jersey 07458: Pearson Education, Inc.

Leavy, P. (2017). Research design. New York: Guilford Press.

Lee, T. W. \& Mowday, R. T. (1987). Voluntarily Leaving an Organization: An Empirical Investigation of Steers and Mowday's Model Turnover. The Academy of Management Journal, Vol. 30(No. 4), pp. pp. 721-743.

Lewis, B. R., Templeton, G. F. \& and Byrd, T. A. (2005). A Methodology for Construct Development in MIS Research. European Journal of Information Systems, 14(4), pp. 388-400.

Lum, L. et al. (1998). Explaining nursing turnover intent: Job satisfaction, pay satisfaction, or organizational commitment. Journal of Organisational Behaviour, 19(3), pp. pp. 305-320. .

Luna-Arocas, R. \& Morley, M. J. (2015). Talent management, talent mindset competency and job performance: the mediating role of job satisfaction. European J. International Management, 9(1), p. pp.28-51.

Luthans, F. (2006. Organizational behavior: an evidence-based approach. New York: McGraw-Hill/Irwin.

Meirina, I., Ferdian, F., Pasaribu \& Suyuthie, H. (2018). The Influence of Work Environment Toward Turnover Intention of Employee of 4 Star Hotels in Padang City. JBHOST 4(2), pp. pp. 1-8.

Mitrovska, S. \& Eftimov, L. (2016). Calculating the Cost for Employee Turnover in the IT Industry. Journal of Human Resource management, 19(1).

Morley, M. (2007). 'Person-organization fit', Journal of Managerial Psychology. 22(2), pp. pp. 109 - 117.

Neuman, W. L. (2014). Social Research Methods: Qualitative and Quantitative Approaches. Seventh Edition ed. Edinburgh Gate: Pearson Education Limited.

Pallant, J. (2007). SPSS Survival Manual. 3rd Ed. ed. New York: McGraw-Hill.

Pasewark, W. \& Strawser, J. (1996). The Determinants and Outcomes Associated. Behavioral, Volume Vol. 8, pp. pp. 91 - 113.

Rossiter, J. R. (2008). Content validity of measures of abstract constructs in management and organizational. British Journal of Management, (4), pp. 380-388. 
Salleh, R., Nair, M. S. \& Harun, H. (2012). Job Satisfaction, Organizational Commitment and Turnover Intention: A Case Study on Employees of a Retail Company in Malaysia. International Journal of Economics and Management Engineering, 6(2).

Sirait, E., Pertiwiwati, E. \& Herawati. (2016). Faktor Faktor Yang Mempengaruhi Kepuasan Kerja Perawat di Ruang Rawat Inap RSUD Haji Boejasin Pelaihari. Program Studi Ilmu Keperawatan Fakultas Kedokteran Universitas Lambung Mangkurat, 4(1), pp. pp. 14-20.

Sugiyono. (2013). Metode Penelitian Kuantitatif Kualitatif dan R\&D. Bandung: Alfabeta.

Suryani \& Hendryani. (2015). Metode Riset Kuantitatif: Teori dan Aplikasi Pada Penelitian Bidang Manajeman dan Ekonomi Islam. Jakarta: PT Fajar Interpratama Mandiri.

Tanadewa Resort \& Spa, Ubud. (2020). Tanadewa Resort \& Spa, Ubud. Retrieved from: https://www.tanadewaubud.com/

Witasari, L. (2009). Analisis Pengaruh Kepuasan Kerja dan Komitmen Organisasional Terhadap Turnover Intentions (Studi Empiris pada Novotel Semarang).

Wolo, P. D. (2015). Analisis Faktor Yang Mempengaruhi Kepuasan Kerja Perawat.

Woods, R. H. \& Macaulay, J. F. (1989). R for Turnover: Retention Program that Work. Cornell Hotel and Restaurant Administration Quarterly, pp. May, pp.78 - 90.

Zeffane, R. M. (1994). Understanding Employee Turnover: The Need for a Contingency Approach. International Journal of Manpower, Vol. 15(No. 10), pp. pp. 22-37. 